University of Nebraska - Lincoln

DigitalCommons@University of Nebraska - Lincoln

\title{
Patch Size and Landscape Effects on Density and Nesting Success of Grassland Birds
}

\author{
Maiken Winter \\ State University of New York \\ Douglas H. Johnson \\ USGS Northern Prairie Wildlife Research Center, Douglas_H_Johnson@usgs.gov \\ Jill A. Shaffer \\ USGS Northern Prairie Wildlife Research Center, jshaffer@usgs.gov \\ Therese M. Donovan \\ University of Vermont, therese.donovan@uvm.edu \\ W. Daniel Svedarsky \\ University of Minnesota
}

Follow this and additional works at: https://digitalcommons.unl.edu/usgsnpwrc

Part of the Other International and Area Studies Commons

Winter, Maiken; Johnson, Douglas H.; Shaffer, Jill A.; Donovan, Therese M.; and Svedarsky, W. Daniel, "Patch Size and Landscape Effects on Density and Nesting Success of Grassland Birds" (2006). USGS Northern Prairie Wildlife Research Center. 235.

https://digitalcommons.unl.edu/usgsnpwrc/235

This Article is brought to you for free and open access by the US Geological Survey at DigitalCommons@University of Nebraska - Lincoln. It has been accepted for inclusion in USGS Northern Prairie Wildlife Research Center by an authorized administrator of DigitalCommons@University of Nebraska - Lincoln. 


\title{
Patch Size and Landscape Effects on Density and Nesting Success of Grassland Birds
}

\author{
MAIKEN WINTER, ${ }^{1,2}$ State University of New York, College of Environmental Sciences and Forestry, 1 Forestry Drive, Syracuse, NY 13210, USA \\ DOUGLAS H. JOHNSON, U.S. Geological Survey, Northern Prairie Wildlife Research Center, 8711 37th Street SE, Jamestown, ND 58401, USA \\ JILL A. SHAFFER, U.S. Geological Survey, Northern Prairie Wildlife Research Center, 8711 37th Street SE, Jamestown, ND 58401, USA \\ THERESE M. DONOVAN, U.S. Geological Survey, Vermont Cooperative Fish and Wildlife Research Unit, University of Vermont, Burlington, VT 05405, USA \\ W. DANIEL SVEDARSKY, Northwest Research and Outreach Center, University of Minnesota, Crookston, MN 56716, USA
}

\begin{abstract}
Current management recommendations for grassland birds in North America emphasize providing large patches of grassland habitat within landscapes that have few forest or shrubland areas. These Bird Conservation Areas are being proposed under the assumption that large patches of habitat in treeless landscapes will maintain viable populations of grassland birds. This assumption requires that patch size and landscape features affect density and nesting success of grassland birds, and that these effects are consistent among years and regions and across focal species. However, these assumptions have not yet been validated for grassland birds, and the relative importance of local vegetation structure, patch size, and landscape composition on grassland bird populations is not well known. In addition, factors influencing grassland bird nesting success have been investigated mostly in small-scale and short-duration studies. To develop management guidelines for grassland birds, we tested the spatial and temporal repeatability of the influence of patch size and landscape composition on density and nesting success of 3 grassland passerines, after controlling for local-scale vegetation structure, climate, and-when analyzing nest successbird density. We conducted our study during 4 years (1998-2001) in 44 study plots that were set up in 3 regions of the northern tallgrass prairie in Minnesota and North Dakota, USA. In these study plots we measured density and nesting success of clay-colored sparrows (Spizella pallida), Savannah sparrows (Passerculus sandwichensis), and bobolinks (Dolichonyx oryzivorus). Statistical models indicated that density was influenced by patch size, landscape, region, and local vegetation structure more so than by local vegetation structure alone. Both magnitude and direction of the response of density to patch size varied among regions, years, and species. In contrast, the direction of landscape effects was consistent among regions, years, and between Savannah sparrows and bobolinks. In each species, this landscape effect was independent of patch size. Nesting success was not clearly influenced by patch size or landscape composition, and none of the factors that influenced avian density also influenced nesting success in any of the 3 species. General statements on "optimal habitat" for grassland birds should therefore be viewed cautiously. Instead, long-term studies in different regions as well as a deeper understanding of the local system are needed to determine which factors are most important for grassland birds in a particular area. (JOURNAL OF WILDLIFE MANAGEMENT 70(1):158-172; 2006)
\end{abstract}

\section{Key words}

Bird density, bobolink, clay-colored sparrow, Dolichonyx oryzivorus, landscape composition, nest success, Passerculus sandwichensis, patch size, replication, Savannah sparrow, Spizella pallida, variability.

A recently proposed strategy to halt or even reverse population declines in grassland songbirds is based on the assumption that large patch size and appropriate landscape composition will result in reproductive rates sufficient for long-term maintenance of grassland bird populations (Henderson and Sample 1995, Fitzgerald et al. 1998. Specifically, this strategy calls for the creation of large core areas of high-quality habitat (such as native prairie) that are surrounded by treeless habitat such as Conservation Reserve Program (CRP) fields, farmland, or small crops, and that are isolated from shrublands and woodlands. A specific combination of core and surrounding landscape is referred to as a Bird Conservation Area (BCA; Henderson and Sample 1995). Large, nearby areas of shrubs and trees are considered to have a negative effect on grassland bird populations because they are known to harbor predators and brood parasites (Gates and Gysel 1978, Winter et al. 2000). Although conceptually the use of BCAs in grassland bird management appears appropriate, identifying sites as potential BCAs may be problematic.

${ }^{1}$ E-mail: mw267@cornell.edu

2 Present address: United States Geological Survey, Fisheries, Wildlife, and Conservation Biology, University of Minnesota, St. Paul, MN 55108, USA
The BCAs may be limited in their applicability because grassland birds may not respond consistently to variation in grassland patch size and the composition of the surrounding landscape. Spatially and temporally replicated studies of forestbreeding birds in the midwestern and northeastern United States suggest responses to patch size and landscape structure are consistent (e.g., Donovan et al. 1995, Robinson et al. 1995, Driscoll and Donovan 2004). However, a consistent response of grassland birds to patch size and landscape composition is less likely because of interannual and interregional changes in distributions of many grassland species (Igl and Johnson 1999; Winter et al. 2005a,b) and interannual variation in nesting success (George et al. 1992, Davis 2003). Such variation is not surprising because high climatic variability causes populations of many grassland birds to fluctuate greatly among regions and years (Ig1 and Johnson 1997). In addition, birds often respond unpredictably to environmental variation because of lags in response time (Wiens et al. 1987). Before developing management guidelines for grassland birds that are based on specific patch sizes and landscape compositions, this variability in grassland systems needs to be considered by addressing 4 main questions: 


\section{How Consistent Are Effects Among Years, Regions, and Species?}

The dangers of short-term and small-scale studies have long been voiced (Wiens 1981). Several studies on grassland passerines have been conducted on a relatively large temporal or spatial scale, such as for more than 3 years (e.g., Walk and Warner 1999, Dieni and Jones 2003, Bollinger and Gavin 2004) or in more than 1 region (e.g., Koford 1999, Johnson and Igl 2001, Ribic and Sample 2001, Herkert et al. 2003). Far fewer studies gathered data on both large temporal and spatial scales (e.g., Best et al. 1997, Davis 2003). However, we know of only 2 published articles that simultaneously quantified both annual and regional variation in density of a grassland passerine (Igl and Johnson 1999, Winter et al. 2005b). Both of these studies showed considerable spatial and temporal variation in the distribution of Le Conte's sparrows (Ammodramus leconteii). Clearly, apparent "rules" that govern species assemblages can change dramatically through time (Wiens 2001). Basing management recommendations on the results of short-term and small-scale studies may therefore be misleading.

2. At Which Habitat Scale-Local, Patch, or Landscape-Do Grassland Birds Respond Most Consistently; That Is, Which Habitat Scale Merits the Most Consideration in Formulating Management Guidelines?

Management guidelines that are developed solely from studies conducted on one habitat scale might focus on an inappropriate spatial scale. However, most published studies on grassland birds investigated the effect of only 1 habitat scale, either the local scale (e.g., Wiens 1969, Best et al. 1997, Scheiman et al. 2003) or the patch scale (e.g., Helzer and Jelinski 1999, Walk and Warner 1999, Winter and Faaborg 1999, Davis 2003). Few grassland bird studies integrated several habitat scales (e.g., Herkert 1994a, Ribic and Sample 2001, Bakker et al. 2002, Renfrew and Ribic 2002, Davis 2004). These latter studies clearly showed that factors at the local, patch, or landscape scales can differ in their relative importance on grassland bird density. However, these studies did not integrate both annual and regional variation in their analyses, and thus did not demonstrate if the observed patterns were consistent among years and regions. We know of only one study on grassland passerine densities that integrated information from habitat features at several scales and tested for interannual and interregional variation: Winter et al. (2005b) showed that variation in Le Conte's sparrow density could be explained by local vegetation structure and year, but patch size, landscape structure, and region had no recognizable effect.

3. Is the Response to Patch Size Dependent on Landscape Composition; That Is, Are There Interactive Effects Between Patch Size and Landscape?

In forest-breeding birds it has been demonstrated that patch effects, such as edge effects, can depend on the surrounding landscape (Donovan et al. 1997, Driscoll and Donovan 2004). In grassland birds, the possible presence of such an interaction has not yet been examined in any published research. If a species' response to patch size were affected by landscape composition, then management plans for grassland patches would need to differ depending on the nature of the surrounding landscape.

\section{Do the Same Factors Influence a Species' Density and Its Reproductive Success?}

Previous studies on grassland birds have indicated that bird density does not always reflect nesting success (Vickery et al. 1992, Hughes et al. 1999). Management guidelines based on bird density alone can therefore be incorrect (Van Horne 1983). It is thus essential to consider reproductive success in management guidelines. Despite this realization, few studies on the effect of patch size and landscape structure on grassland birds have investigated if density is an appropriate indicator of nesting success (Vickery et al. 1992, Winter and Faaborg 1999, Davis 2003).

Depending on the answers to the above 4 questions, BCAs might not always constitute the most cost-effective solution to grassland bird conservation. For example, the requirement for a large core area of high-quality habitat might undervalue smaller grassland patches within the landscape matrix (see Management Implications below; Davis 2004).

Between 1998 and 2001, we evaluated the BCA concept by investigating effects of patch size and landscape composition on density and nesting success of grassland birds in the northern tallgrass prairie of North America. The BCA concept implicitly assumes that local vegetation structure is of high quality, and does not take climatic variables or local bird density into account. Therefore, we assessed whether patch size and landscape metrics influence density and nesting success after controlling for local vegetation structure, climate, and-for analyzing nest successbird density (Winter et al. 2005). We also asked whether effects of patch size and landscape metrics varied spatially or temporally. We focused on the 3 most abundant grassland-nesting passerines: the clay-colored sparrow, Savannah sparrow, and bobolink. To our knowledge, no single study has previously incorporated large regional and temporal scales in the analysis of local factors, patch size, and landscape on both density and nesting success of several species of grassland birds.

\section{Methods}

\section{Study Area and Study Design}

The study was conducted in 3 regions in the northern tallgrass prairie of the United States (Fig. 1) that were about $50 \mathrm{~km}$ apart: 1) east of Moorhead, Minnesota, in Becker, Mahnomen, Clay, and Wilkin counties (Glyndon; 1998-2001); 2) east of Crookston, Minnesota, in Polk County (Crookston; 1998-2001); and 3) in southeastern North Dakota at the Sheyenne National Grassland, in Richland and Ransom counties (Sheyenne; 1999-2001). Formerly connected in glacial times as a vast expanse of tallgrass prairie that evolved under the influence of the rising and falling of glacial Lake Agassiz, the prairie landscape is now fragmented by agriculture and urbanization (Chapman et al. 1998). Each of our study regions has some unique characteristics, yet each retains the vital characteristics of the tallgrass prairie ecosystem. Glyndon represents the Agassiz Beach Ridges, Crookston represents the interface between tallgrass prairie and aspen parkland, and Sheyenne represents the sandy delta that supports savannah habitats. We assumed that if a species' response differed among such small-scale regions that variation at larger scales was highly likely. Within these regions, we targeted for study tracts of land that were owned by the U.S. Fish and Wildlife Service, U.S.D.A. 


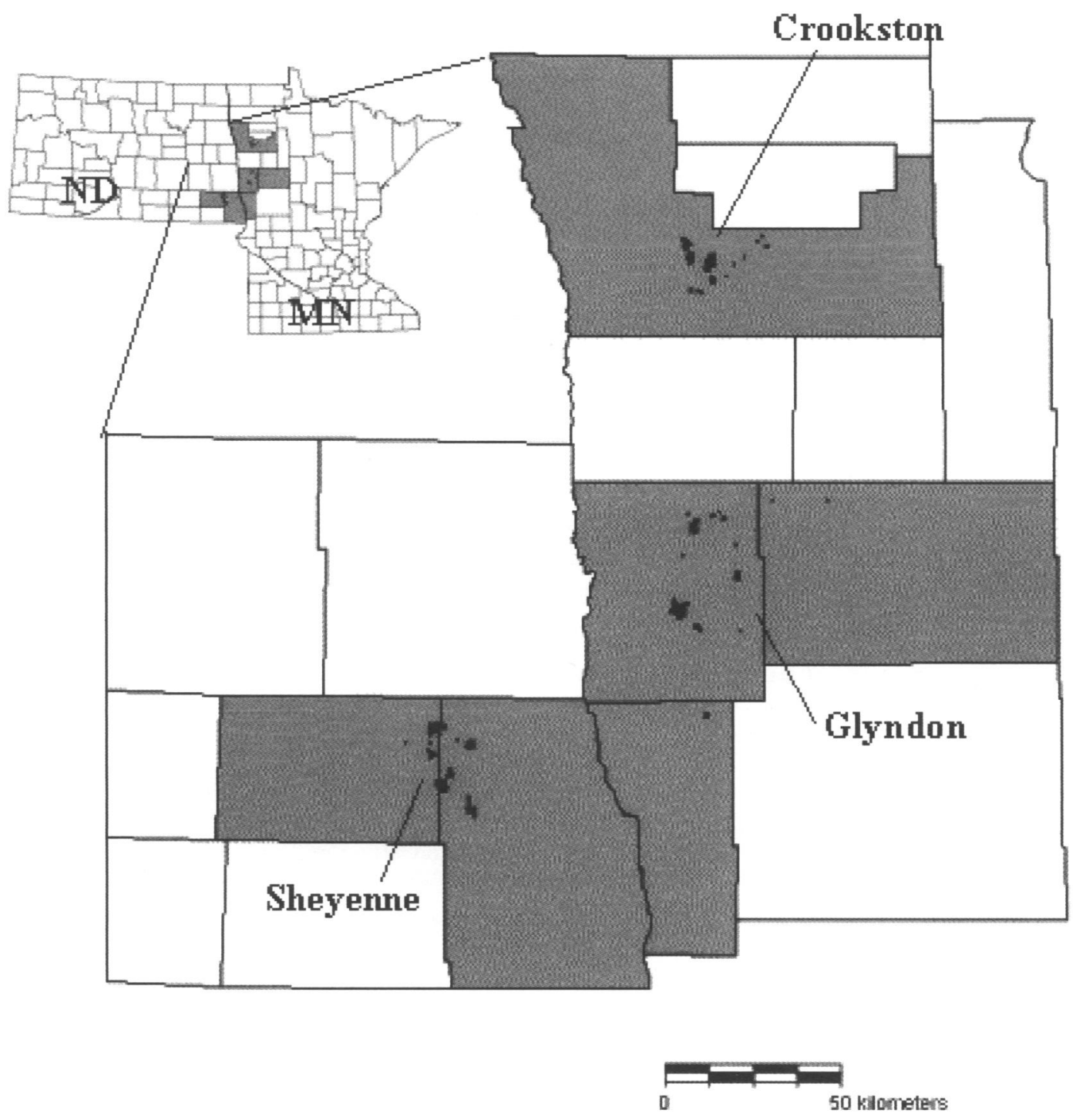

Figure 1. Location of study plots within the 3 study regions in southeastern North Dakota and northwestern Minnesota, USA.

Forest Service, Minnesota Department of Natural Resources, and The Nature Conservancy. Whereas prairie patches in Sheyenne were managed by rotational grazing, prairie patches in the other two regions were managed by prescribed burning.

In each region we established 11-18 study plots in which we determined density and nesting success of grassland-nesting birds (Appendix 1). We selected study plots based on the following criteria: 1) they were native prairie; 2 ) cover by shrubs (mostly western snowberry [Symphoricarpos occidentalis] and meadowsweet [Spiraea alba]) and trees (mostly quaking aspen Populus tremuloides and willow Salix spp.) within the study plots was as low as possible $(\bar{x}=2.43 \pm 0.33 \%)$; and 3$)$ they were located within a prairie patch that represented an extreme in size and landscape composition. These extremes were dictated by the size and location of prairie patches available in the region, and included small patches $(<65 \mathrm{ha})$ within a treeless landscape $(<10 \%$ shrubs and trees in the landscape), small patches within a wooded landscape ( $>10 \%$ shrubs and trees in the landscape), large patches $(>100 \mathrm{ha}$ ) within a treeless landscape, and large patches within a wooded landscape. We included every prairie that fit our selection criteria and that was logistically feasible to study. Because of a shortage of prairies that fit our criteria, we included a few grassland areas that were nonnative reseeded grassland (Appendix 1). Such grasslands were not used for gathering information on nesting success. Thus, all selected study plots were within native or restored prairie of similar vegetation structure and composition. Depending on the size of the prairie patch, the size of the study plots varied between 1.5 and 20 ha ( $\bar{x}=10.6$ ha; Appendix 1).

Study plots were located as far from a woody edge as possible to minimize the influence of edge avoidance by birds (Fletcher and Koford 2003, Bollinger and Gavin 2004) and to minimize potential influence of increased nest predation close to edges (Winter et al. 2000). Study plots were marked with flags or wooden laths at 50-m intervals along transects that were $100 \mathrm{~m}$ apart. The corners of each study plot were marked with rebar, and their locations were recorded with a Geographical Positioning System unit.

\section{Study Species}

We focused on the 3 grassland bird species that were most common in our study plots: Clay-colored sparrow, Savannah sparrow, and bobolink. Clay-colored sparrows inhabit shrubby or 
densely vegetated grasslands, and are largely confined to the northern Great Plains (Knapton 1994). Savannah sparrows occur in relatively treeless grasslands throughout most of northern North America (Wheelwright and Rising 1993), and bobolinks inhabit treeless grasslands in the central and northeastern region of the United States and in southern Canada (Martin and Gavin 1995). Clay-colored sparrows prefer to place their nests within shrubs, whereas Savannah sparrows and bobolinks place their nests on or close to the ground within grasses or dead plant material (Winter et al. 2004). Of the species investigated, bobolink is the only species that has consistently been classified as area sensitive (Bollinger and Gavin 1992, Herkert 1994b), but this area sensitivity might be density dependent (Renfrew and Ribic 2002). Each of the 3 species has declined in abundance across most of North America during 1966-2003 (Sauer et al. 2004). A deeper understanding of the factors that influence population change in these species is necessary to develop more effective management guidelines to decrease or even reverse these declines.

\section{Data Collection}

We conducted bird surveys between 0500 and 1000 daylight savings time by slowly walking the study plot transects. During each census, we marked on field maps the location and flight paths of all birds heard or seen to minimize the probability of double counting. Censuses were conducted twice each year between the end of May and early July by M. W. (1998 and 2000), and by J. A. S. (1999 and 2001). We did not census during strong wind ( $>35 \mathrm{~km} / \mathrm{hour}$ ), rain, or low visibility. The maximum count of a species on a plot was used to determine its density (number of males/100 ha).

Nesting success of birds was assessed on 29 of the 44 study plots (Appendix 1) by monitoring eggs and young until a nest was found empty or inactive. Observers located nests by looking for nests after flushing birds or observing bird behavior indicative of nesting birds (Winter et al. 2003). Nests were marked with a flag $5 \mathrm{~m}$ to the north of the nest and were revisited every 3 to 4 days to ascertain their status and incidence of brood parasitism. A nest was considered successful if it fledged at least 1 young of the parental species.

Vegetation characteristics of each study plot and at each nest were evaluated to determine the associations between density of each species and habitat characteristics, and the associations between reproductive success and microhabitat features (for a detailed description see Winter et al. 2005a). We visually estimated the distance of each nest to the nearest shrub $(<2 \mathrm{~m}$ high) or tree ( $\geq 2 \mathrm{~m} \mathrm{high}$ ). The distance of a nest to shrubs was correlated to the distance of a nest to trees $(r=0.25, P<0.001, n$ $=1,754$ nests). We assumed that trees have a greater influence on nesting success because they provide taller perches for avian nest predators and brown-headed cowbirds. We therefore used only the distance of a nest to trees in all analyses.

\section{Patch Size and Landscape Measurements}

We used the following criteria to delineate the size of a prairie patch for statistical analyses: 1) hay meadows and CRP fields were not part of the prairie patch but were considered part of a treeless landscape; 2) 4-lane and 2-lane roads with disturbed roadsides were considered barriers, whereas internal or two-lane roads without a disturbed roadside were not considered barriers and did not delineate the edge of a patch; 3 ) wooded strips or open-water wetlands that were at least $20 \mathrm{~m}$ wide and extended across at least $75 \%$ of any particular study patch were considered barriers and such dissected patches were considered 2 separate patches; and 4) patches bordering each other only at 1 corner or up to $10 \%$ were considered 2 separate patches.

We imported digital orthophoto quads (DOQs) into Map and Image Processing System, versions 6.6 and 6.7 (Microimages, Inc., Lincoln, Nebraska; http://www.microimages.com) to determine the size of the patch in which each study plot was embedded. The DOQs for the Minnesota and North Dakota sites were obtained in 1991 and 1997, respectively. These images also were used to delineate the amount of shrubs and trees within study plots and within $200-\mathrm{m}$ and $1-\mathrm{km}$ buffer zones. Buffer zones included the area of the study plot. The percentage of shrubs and trees within a $200-\mathrm{m}$ buffer zone was highly correlated with the percentage of shrubs and trees within a $1-\mathrm{km}$ buffer zone $(r=$ $0.78, P<0.001, n=44$ study plots). We assumed that the percentage of shrubs and trees in the immediate vicinity of the study plots had a larger impact on the distribution of nest predators and brown-headed cowbirds within the study plots. Therefore, we used only the percentage of shrubs and trees within a 200-m buffer zone in all analyses and refer to it as the "tree and shrub component in the landscape" (Appendix 1).

\section{Data Analysis}

Because study sites were nested within each region, and the study was conducted during a 4-year period, we used a repeated analysis with nested design to investigate both density and nesting success. Models included both fixed effects (vegetation variables, patch size, and landscape variables) and random effects (year and region). To analyze density data, we used PROC MIXED in SAS (SAS 1999, Littell et al. 1996). We used GLIMMIX, a SAS macro for generalized linear mixed models (Wolfinger and O'Connell 1993), to analyze data on nesting success. Daily probabilities of nesting success/failure (i.e., Mayfield estimates) were calculated using logistic-exposure models (Shaffer 2004). This method allows for unknown dates of nest failure and accommodates nest-specific covariates. For this analysis we split the data into 2 nesting intervals (before and after the penultimate check date), such that the number of observations used in the analysis was greater than the number of nests (the number of observations should not be confused with the number of nest checks). We used Akaike's Information Criterion adjusted for

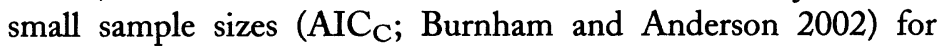
model selection for analyses of both density and nesting success.

In a previous article (Winter et al. 2005c), we evaluated the influence of local vegetation structure (percent cover by different vegetative forms, litter depth, vegetation height, and visual obstruction) and climate on density and nest success. In addition, we investigated the influence of a species' density on its nesting success. We used an information-theoretic approach (Burnham and Anderson 2002) to determine the most parsimonious model. We demonstrated that certain vegetation and climatic variables influenced bird density, and that some vegetation and climatic variables, as well as bird density, influenced nesting success (Table 1).

Because the BCA concept does not explicitly incorporate vegetation and climatic variables or bird density, it is important to control for these factors to test adequately the BCA concept. 
Table 1. Base models showing the effect of vegetation structure within the study plot on bird density and nest success of 3 species of grassland birds in the northern tallgrass prairie, USA, 1998-2001 (Winter et al., 2005a). The base models were subsequently used to examine whether distance to trees, patch size, and the percentage of shrubs and trees within a 200-m buffer zone improve the fit of models.

\begin{tabular}{|c|c|c|}
\hline Response variable & Species & Variables included \\
\hline \multirow[t]{3}{*}{ Density } & Clay-colored sparrow & $\begin{array}{l}\text { Year, Region, Woody cover } \\
\text { (Negetation height) }^{2}\end{array}$ \\
\hline & Savannah sparrow & $\begin{array}{c}\text { Region } \\
\text { (Litter depth) }\end{array}$ \\
\hline & Bobolink & Region $\times$ Vegetation height \\
\hline \multirow[t]{3}{*}{ Nest success } & Clay-colored sparrow & $\begin{array}{l}\text { Nest cover } \times \text { Date } \\
\text { Clay-colored sparrow density }\end{array}$ \\
\hline & Savannah sparrow & Savannah sparrow density \\
\hline & Bobolink & $\begin{array}{c}\text { Bobolink density } \times \text { Palmer } \\
\text { Drought Index }\end{array}$ \\
\hline
\end{tabular}

Therefore, we used the best models (hereafter, base models) from Winter et al. (2005a) as a starting point for the BCA investigations (Table 1). To these best models we added the variables of interest in 3 separate steps: In step 1 we evaluated models that included both base variables and patch size and determined the model that was best supported by the data. We called this best-fitting model the Base 1 model (Table 2). In step 2 , we added the tree and shrub component in the landscape to the Base 1 model. To the best-supported model in step 2 (Base 2), we then-in the third step-added terms that specifically tested the interaction between patch size and landscape variables (i.e., the BCA concept). The best-fitting model from this third step was considered our final model. For the nest success analysis, we sequentially added the following variables to the base models: 1 ) distance to the nearest tree, 2) patch size, 3) the shrub and tree component in the landscape, and 4) the interaction between patch size and landscape metrics. We added the distance to the nearest tree to the analysis of nest success because previous studies have indicated that proximity of a nest to woody vegetation can increase its likelihood of being depredated (Winter et al. 2000). This stepby-step analytic procedure was selected because 1) it controls for factors other than patch size and landscape metrics that might be influencing bird density or nest success; 2) it minimizes the number of models examined; and 3) it follows a hierarchical pattern, ending with the broadest encompassing scales that test for interactions between patch size and landscape metrics.

Our model selection "rules" were as follows. At each step, we compared the appropriate base model with several additional models that included the variable of interest. For example, in step 1 for the density analyses, we compared 5 models: 1 ) the base model alone, 2) the base model plus patch size effects, 3) the base model plus patch size $\times$ year, 4) the base model plus patch size $\times$ region, and 5 ) the base model plus patch size $\times$ year and patch size $\times$ region. We then ranked the models according to their $\triangle \mathrm{AIC}_{\mathrm{C}}$ values and used the model with the lowest $\mathrm{AIC}_{C}$ value as the Base 1 model. Where there was support for more than 1 model $\left(\Delta \mathrm{AIC}_{\mathrm{C}}<4\right)$, we used the most inclusive model as the base model for the following step. The most inclusive model was that model that included the largest number of variables. In step 2, we compared the Base 1 model from step 1 with 4 additional models that included landscape metrics, landscape $\times$ year or landscape $\times$ region, and landscape $\times$ year plus landscape $\times$ region. The selected model from step 2 (Base 2 ) was then used as a base model for step 3 , which added the patch size $X$ landscape interaction. The best model from step 3 was considered our final model for the density analyses. If both models within step 3 had $\triangle \mathrm{AIC}_{\mathrm{C}}$ value $<4$, we included them in a model-averaging

Table 2. Final model for bird density was determined by sequentially adding variables to the base model (from Table 1) for each of 3 grassland-nesting bird species. In the first step, patch size (Sz) was added to the base model $(B)$ as a single or interactive term with region $(R)$ and year $(M)$. The best fitting or most inclusive model with $\triangle A \mathrm{AC}_{\mathrm{C}}<4$ (bold print) was chosen as the new base model (B1). In the second step the shrub and tree component within a 200 -m buffer zone $(\mathrm{L})$ was added to $\mathrm{B} 1$ as single or interactive terms with region and year. The best fitting or most inclusive model from this step (bold) was chosen as the new base model (B2) for the final step, in which the interactive term between $S z$ and $L$ was added. Data were collected in study plots situated in 3 regions of the northern tallgrass prairie, USA, 1998-2001 ( $n=160$ plot-years). All parameters were estimable, and all models included 2 random effects (year and plot[region]). The number of estimable parameters $K$ is therefore the number of variables in the model plus 2.

\begin{tabular}{|c|c|c|c|c|c|c|}
\hline \multirow[b]{2}{*}{ Model variables } & \multicolumn{2}{|c|}{ Clay-colored sparrow } & \multicolumn{2}{|c|}{ Savannah sparrow } & \multicolumn{2}{|c|}{ Bobolink } \\
\hline & $\Delta A \mid C_{C}{ }^{a}$ & $w_{t} t^{b}$ & $\triangle A \mid C_{C}$ & Wt & $\triangle A \mid C_{C}$ & Wt \\
\hline \multicolumn{7}{|l|}{ 1. Patch size added } \\
\hline B & 4.24 & 0.07 & 5.08 & 0.06 & 0.00 & 0.54 \\
\hline$B+S z$ & 6.52 & 0.02 & 6.70 & 0.03 & 2.18 & 0.18 \\
\hline $\mathrm{B}+\mathrm{Sz} \times \mathrm{R}$ & 3.44 & 0.11 & 0.00 & 0.80 & 2.35 & 0.17 \\
\hline$B+S z \times Y$ & 2.33 & 0.19 & 13.15 & 0.00 & 5.84 & 0.03 \\
\hline $\begin{array}{l}B+S z \times Y+S z \times R \\
\text { 2. Landscape added }\end{array}$ & \multicolumn{5}{|c|}{ 2. Landscape added } & 0.08 \\
\hline B1 & 21.72 & 0.00 & 13.13 & 0.00 & 10.86 & 0.00 \\
\hline$B 1+L$ & 18.45 & 0.00 & 0.00 & 0.51 & 10.94 & 0.00 \\
\hline$B 1+L \times R$ & 16.68 & 0.00 & 0.23 & 0.45 & 7.27 & 0.03 \\
\hline$B 1+L \times Y$ & 17.83 & 0.00 & 5.45 & 0.03 & 11.40 & 0.00 \\
\hline$B 1+L \times Y+L \times R$ & 0.00 & 1.00 & 10.24 & 0.00 & 0.00 & 0.96 \\
\hline \multicolumn{7}{|c|}{ 3. Patch size $\times$ Landscape added: final model } \\
\hline B2 & 0.00 & 0.78 & 0.00 & 0.76 & 0.00 & 0.70 \\
\hline $\mathrm{B} 2+\mathrm{Sz} \times \mathrm{L}$ & 2.56 & 0.22 & 2.31 & 0.24 & 1.70 & 0.30 \\
\hline
\end{tabular}

a $\triangle A I C_{C}$ is the difference between a model and the best-fitting model, adjusted for small sample sizes.

${ }^{b}$ Akaike weights indicate the importance of 1 model relative to the other models. 

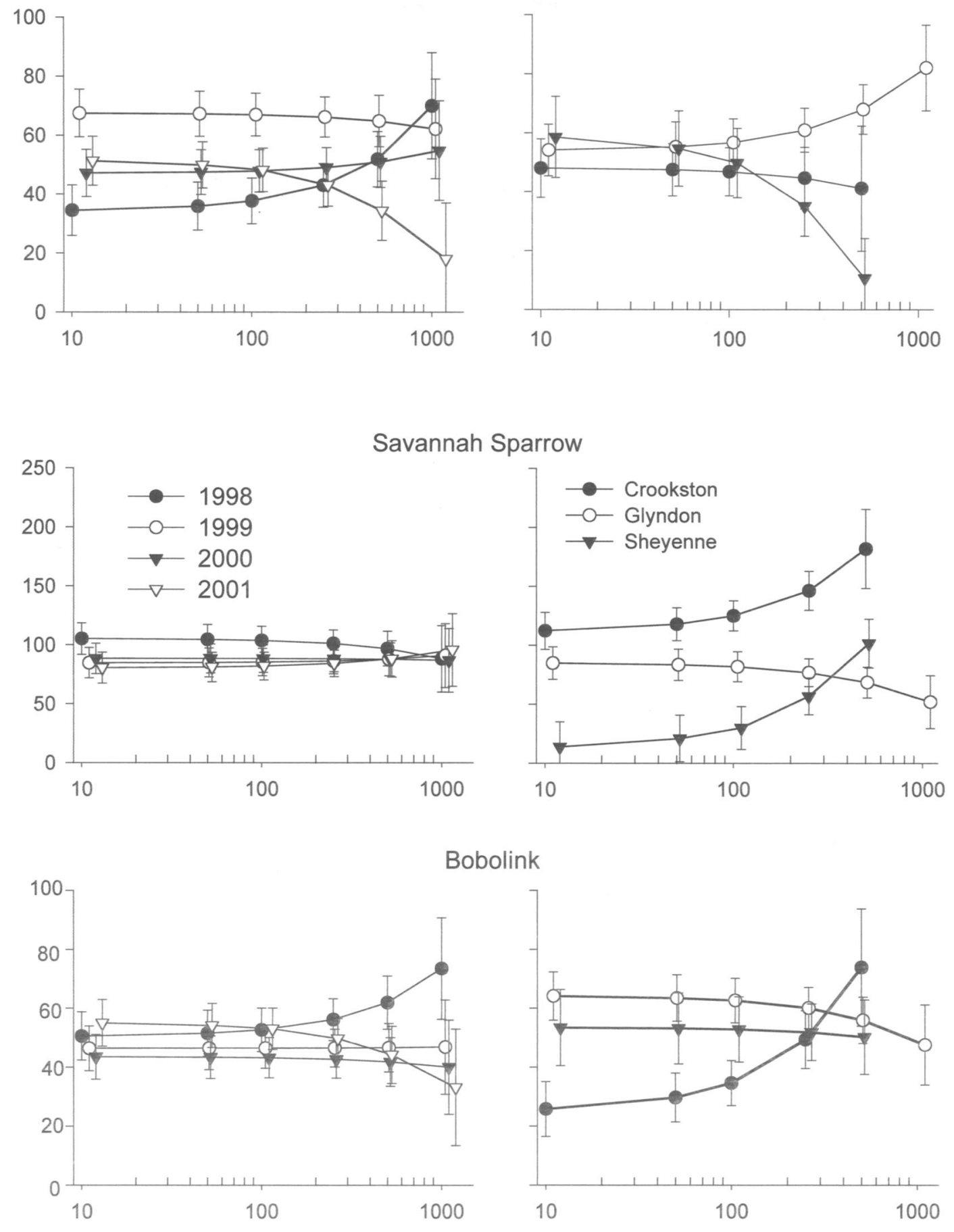

Bobolink

\section{Patch size (log-scale)}

Figure 2. Estimated values of density ( $\pm \mathrm{SE}$ ) in relation to patch size (log scale) for 3 grassland-nesting passerines. We derived the predicted values at arbitrary patch size intervals from a model including patch size, year, and the patch size $\times$ year interaction. Interactive effects indicate that patch size effects were not consistent among years (left column) and regions (right column). Patches of tallgrass prairie were located in northwestern Minnesota (Crookston and Glyndon; 1998-2001) and southeastern North Dakota (Sheyenne; 1999-2001), USA.

analysis to derive estimates and $90 \%$ confidence intervals for each variable in the model (Anderson et al. 2000). To display interactive effects, we plotted estimated values and their standard errors (Figs. 2 and 3).

The unbalanced design of our study (Sheyenne region was not added until the second year of the study) poses a potential problem: If patterns at Sheyenne consistently differ from those in the other 2 regions, then any interannual variation might be caused by the absence of Sheyenne in 1998. We approached this problem graphically, separately for each species: by plotting density against 


\section{Clay-colored Sparrow}
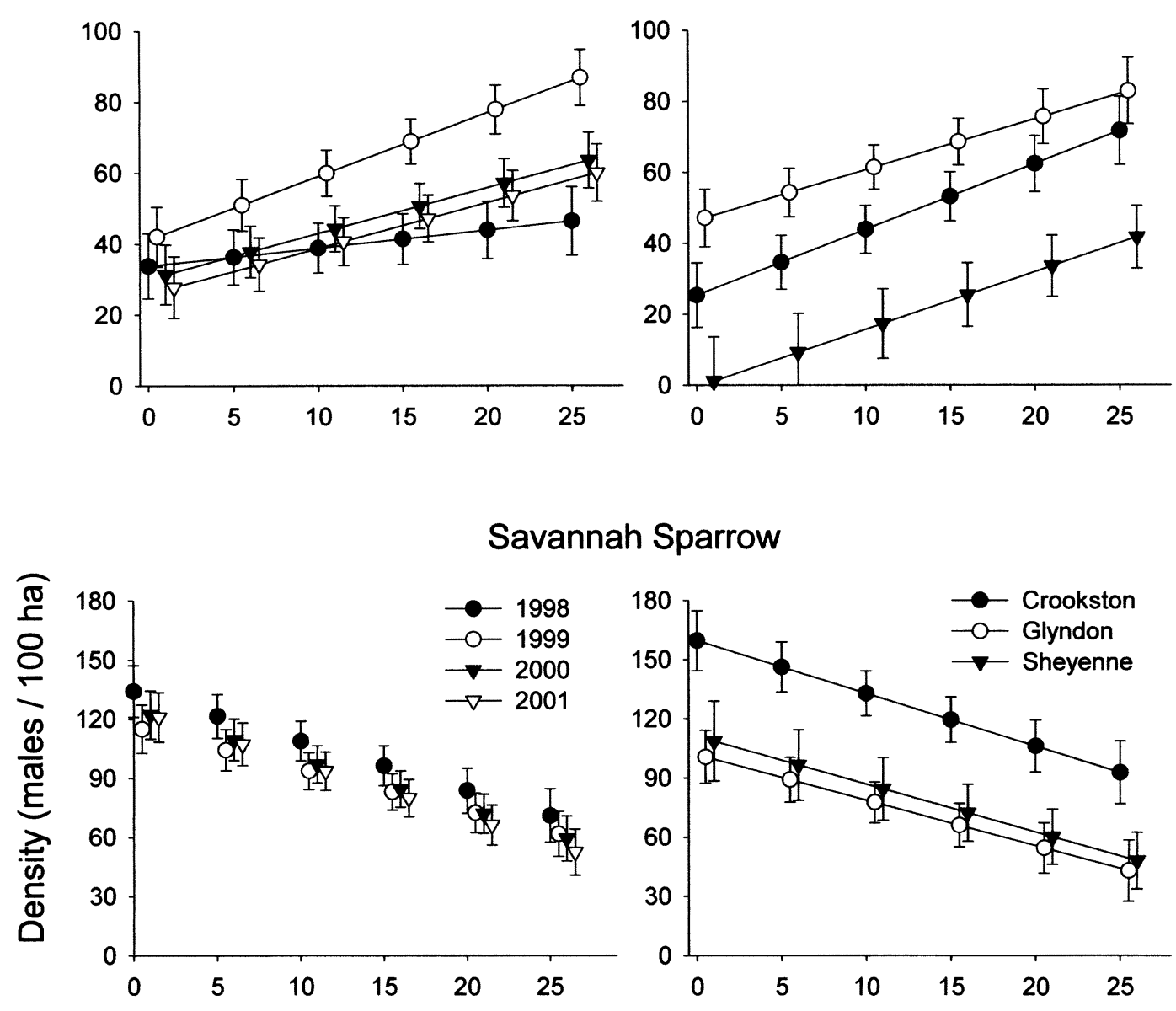

\section{Bobolink}
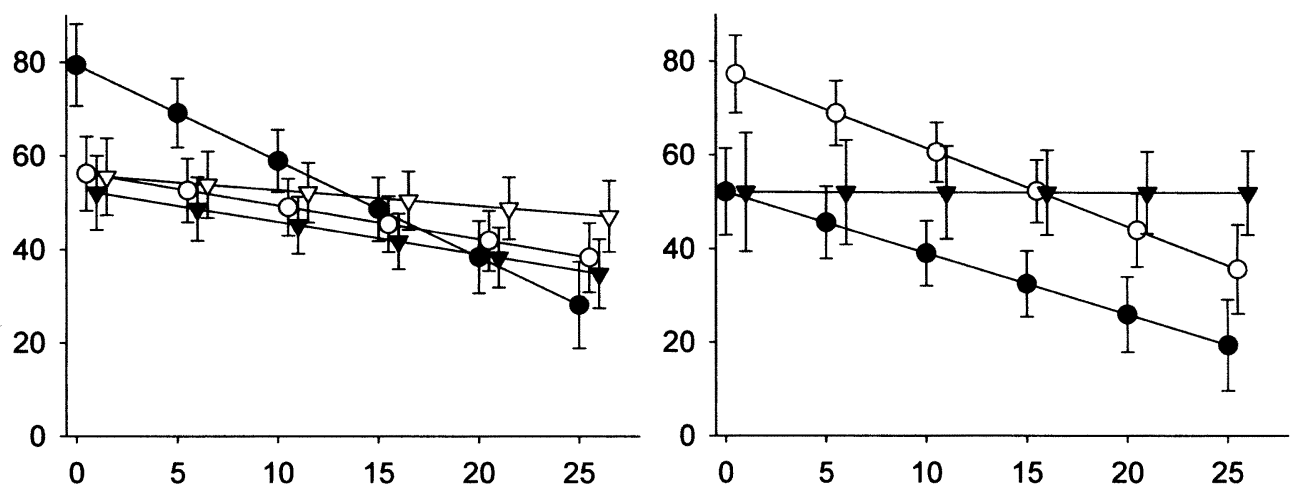

Shrub and tree cover within $200 \mathrm{~m}(\%)$

Figure 3. Estimated values of density ( $\pm \mathrm{SE}$ ) of 3 grassland-nesting passerines in relation to the percentage of shrubs and trees within $200 \mathrm{~m}$. We derived the predicted values and SE at arbitrary landscape intervals from a model including landscape, year, and the landscape $\times$ year interaction. Interactive effects indicate that the magnitude of the effect of the shrub and tree component in the landscape was not consistent among years (left column) and regions (right column). Patches of tallgrass prairie were located in northwestern Minnesota (Crookston and Glyndon; 1998-2001) and southeastern North Dakota (Sheyenne; 19992001), USA.

patch size separately for each region and year, we could show that patterns varied both among regions and among years within regions, indicating that annual variation was not only caused by regional variation in density (M. Winter et al., State University of New York, unpublished data).

\section{Results}

\section{Patch Size Effects on Density}

For 2 of the 3 species, models that included patch size were better supported by the data than models that included base variables only 
(Table 2, step 1). Patch size effects on bird density varied among years and regions, although the confidence limits mostly included zero (Appendix 2) such that we cannot be certain of the direction and magnitude of the response. The best-fitting and most inclusive model for clay-colored sparrows had almost 9 times more support than the base model alone (based on AIC weights; Table 2). The magnitude and the direction of the response to patch size varied among years and regions (Appendix 2; Fig. 2) because the model included both patch size $\times$ year and patch size $\times$ region interactions. The only model predicting Savannah sparrow density that was strongly supported by the data $\left(\Delta \mathrm{AIC}_{\mathrm{C}}<4\right)$ had 13 times more support than the base model alone (Table 2). This model indicated that patch size effects varied among regions (Appendix 2; Fig. 2), with densities increasing as patch size increased in 2 of the 3 regions. For bobolinks, the base model was the most parsimonious model $\left(\triangle \mathrm{AIC}_{\mathrm{C}}=0\right)$. However, the most inclusive model also was supported $\left(\triangle \mathrm{AIC}_{\mathrm{C}}=3.96\right)$, indicating that patch size effects varied somewhat among years and regions (Appendix 2; Fig. 2).

Regional differences in the response to patch size might have been caused partly by the difference in size distribution of grassland patches among regions. In Crookston, mean patch size tended to be smaller than in the other 2 regions (Tukey-Kramer multiple comparison test: $\bar{x}=122.3 \pm 41.1$ ha in Crookston versus $\bar{x}=291.2$ \pm 108.0 ha in Glyndon, and $\bar{x}=261.4 \pm 87.6$ ha in Sheyenne, $P=$ $0.15, n=44$ plots). In addition, the range in patch sizes was much lower in Crookston (range $=492 \mathrm{ha}$ ) than in Glyndon (range = $1,242 \mathrm{ha}$ ) and Sheyenne (range $=824 \mathrm{ha}$ ). In small prairie patches, bird abundance or density might be more strongly influenced by area sensitivity and by edge-avoidance behavior. Therefore, patch size effects might be more likely to be manifested in an array of relatively small prairies, as occurred in the Crookston region. However, patch size did not have a generally stronger effect at Crookston than in the other 2 regions (Fig. 2).

\section{Landscape Effects on Density}

Adding the shrub and tree component at a landscape scale to the base + size model (Table 2, step 2) resulted in the best model for each species. For each species, the most inclusive model contained interaction terms, indicating that effects of the shrub and tree component in the landscape varied among years and regions. These effects were more clearly estimated than those of patch size because in many cases confidence intervals did not include zero (Appendix 2).

We expected a stronger response in density to landscape composition in the region with the largest percentage and with the widest range of shrubs and trees within a $200-\mathrm{m}$ buffer. Sheyenne tended to have a higher average percentage of shrubs and trees than the Crookston or Glyndon regions (Tukey-Kramer test: $\bar{x}=20.5 \pm 6.2 \%$ in Sheyenne versus $\bar{x}=11.9 \pm 1.7 \%$ in Crookston and $\bar{x}=10.8 \pm 3.1$ in Glyndon; $P=0.09, n=44$ plots). In addition, the range of shrubs and trees in the landscape was greater at Sheyenne than in the other 2 regions $(55.9 \%$ versus $34.5 \%$ in Crookston and $49.2 \%$ in Glyndon). However, the response to shrubs and trees was either similar among regions or weakest at Sheyenne (Fig. 3).

In clay-colored sparrows, the most inclusive model was well supported by the data (Table 2, step 2). In each year and region, density of clay-colored sparrows increased with the shrub and tree component in the landscape; this increase varied slightly among years and regions (Fig. 3). The most inclusive model for Savannah sparrow density that had a $\triangle \mathrm{AIC}_{\mathrm{C}}<4$ included the interactive effect between the shrub and tree component in the landscape and region (Table 2, step 2). Densities of Savannah sparrows decreased with an increasing shrub and tree component in the landscape (Fig. 3); the magnitude of this decrease varied slightly among regions (Appendix 2). The most inclusive model (Table 2, step 2) for bobolink density incorporated both landscape $\times$ region and landscape $\times$ year interactions. That model (with Akaike weight $=$ 0.96) had more than 30 times the support than the next best model, which did not include the landscape $\times$ year interaction. Bobolink density decreased in each region and in each year with increasing percentage of shrubs and trees in the landscape (Appendix 2). However, the magnitude of this decrease differed among years and regions (Fig. 3 ).

The base + size + landscape models were not improved by adding the patch size $\times$ landscape interaction (Table 2 , step 3 ) for any species, and the estimated effect derived from model averaging was close to zero (Appendix 2). Thus, we did not find compelling evidence that the effect of patch size on density varied depending upon the shrub and tree component in the landscape.

\section{Patch Size and Landscape Effects on Nesting Success}

We expected nesting success to be higher in large prairie patches and in patches that were surrounded by treeless landscapes. In reality, nesting success was not consistently higher in large or treeless prairie patches (Table 3 ). The addition of certain variables to the base model resulted in at least 1 model that had $\Delta \mathrm{AIC}_{\mathrm{C}}<4$ in most steps (Table 4). However, compared with the final model, the base model had 17 times the support (Akaike weight $=0.945$ ) for clay-colored sparrows, 9 times the support for Savannah sparrows (Akaike weight $=0.915$ ), and 13 times the support for bobolinks (Akaike weight $=0.930$ ). As a result, model-averaged parameter estimates for the final model indicated that neither distance to the nearest tree, patch size, nor the shrub and tree component in the landscape had any strong or consistent effect on nesting success (Appendix 3). One might argue that the inclusion of bird density in the base model canceled out the effect of patch size on nesting success because bird density was somewhat affected by patch size (Table 3). However, patch size did not influence nesting success of any of the 3 species, even when we excluded bird density from the analyses ( $P>0.30$ for patch size in each species).

We did not find strong evidence that the effect of patch size varied depending upon the shrub and tree component in the landscape. Models that included interactive effects between patch size and the shrub and tree component in the landscape had relatively strong support compared with the final model (Table 4, step 4). However, the estimated effect derived from model averaging was close to zero (Appendix 3).

In summary, we did not find any factor that influenced both density and nesting success in any of the 3 species. However, several factors affected density of each of the 3 species: patch size, percentage of shrubs and trees in the landscape, and region were included in density models of each species, even though the direction or magnitude of the effect varied among species. None of the investigated factors influenced nesting success of any species. 
Table 3. Mayfield nest success rates ${ }^{a}$ and (in parentheses) number of nests in small ( $<65 \mathrm{ha}$ ) and large ( $>100$ ha) grassland patches that are surrounded by wooded (>10\% cover by shrubs and trees in a 200-m buffer) and treeless (<10\% cover) landscape. Nesting data are summed over 4 years (1998-2001) and 3 tallgrass prairie regions in northwestern Minnesota and southeastern North Dakota, USA.

\begin{tabular}{|c|c|c|c|c|c|}
\hline \multirow[b]{2}{*}{ Species } & \multirow[b]{2}{*}{ Region } & \multicolumn{2}{|c|}{ Patch size } & \multicolumn{2}{|c|}{ Landscape } \\
\hline & & Small & Large & Wooded & Treeless \\
\hline \multirow[t]{3}{*}{ Clay-colored sparrow } & Crookston & $0.24(130)$ & $0.35(141)$ & $0.31(162)$ & $0.28(109)$ \\
\hline & Glyndon & $0.22(95)$ & $0.28(255)$ & $0.22(188)$ & $0.32(162)$ \\
\hline & Sheyenne & $0.24(161)$ & $0.11(10)$ & $0.23(168)$ & $0.13(3)$ \\
\hline \multirow[t]{3}{*}{ Savannah sparrow } & Crookston & $0.37(200)$ & $0.30(301)$ & $0.39(131)$ & $0.31(370)$ \\
\hline & Glyndon & $0.34(30)$ & $0.23(61)$ & $0.31(19)$ & $0.25(72)$ \\
\hline & Sheyenne & $0.04(12)$ & $0.22(78)$ & $0.11(19)$ & $0.21(71)$ \\
\hline \multirow[t]{3}{*}{ Bobolink } & Crookston & $0.37(60)$ & $0.14(90)$ & $0.41(38)$ & 0.17 (112) \\
\hline & Glyndon & $0.16(32)$ & $0.32(62)$ & $0.12(20)$ & $0.29(74)$ \\
\hline & Sheyenne & $0.11(26)$ & $0.14(41)$ & $0.07(41)$ & $0.29(26)$ \\
\hline
\end{tabular}

${ }^{a}$ Rates give the probability that a nest survives incubation and nestling periods, assuming 20 days for clay-colored sparrows, 21.5 days for Savannah sparrows, and 24 days for bobolinks.

\section{Discussion}

\section{Response of Bird Density to Patch Size}

The response of bird density to patch size was not consistent among years, regions, or species in our tallgrass study system. Similarly, in the northern mixed-grass prairie the effect of patch size on the abundance of some grassland passerines varied among regions (Johnson and Igl 2001), years (Igl and Johnson 1999, Davis 2003), and bird species (Davis 2003). Although we cannot identify the causes of this variation, we know that it was probably not due to regional differences in either patch size or in the shrub and tree component in the landscape. We believe this because the observed variability in bird density was mainly caused by variation among prairies within regions and by annual variation within prairies, and not by variation among years and regions (Winter et al. 2005a).

Patch size had a relatively minor effect on bird density, possibly because mean patch size was relatively large $(\bar{x}=226.1$ ha,

Table 4. The final model for nesting success was determined by sequentially adding variables to the null model. Variables include: 1) the base model (B, Table 1); 2) the distance of a nest to a tree (Tree), and its interactions with region (R) and year ( $\mathrm{Y}$; 3) Patch size (Sz) and its interaction with region and year; and 4) the percentage of shrubs and trees within a $200-\mathrm{m}$ buffer zone (L), and interactions with region and year. At each step we kept the best-fitting or most inclusive model with $\triangle \mathrm{AIC}_{\mathrm{C}}<4$ (italic print) as base model for the following step. Data were collected for 3 grassland-nesting passerines in study plots situated in 3 regions of the northern tallgrass prairie, USA, 1998-2001. All parameters were estimable, and all models included 2 random effects (year and plot[region]). The number of estimable parameters $K$ is therefore the number of variables in the model plus 2.

\begin{tabular}{|c|c|c|c|c|c|c|}
\hline \multirow[b]{2}{*}{ Effect } & \multicolumn{2}{|c|}{$\begin{array}{l}\text { Clay-colored sparrow } \\
\text { (obs }=1000, n=696)^{a}\end{array}$} & \multicolumn{2}{|c|}{$\begin{array}{l}\text { Savannah sparrow } \\
\text { (obs }=757, n=576 \text { ) }\end{array}$} & \multicolumn{2}{|c|}{$\begin{array}{c}\text { Bobolink } \\
\text { (obs }=360, n=262 \text { ) }\end{array}$} \\
\hline & $\Delta A \mid C_{C}{ }^{b}$ & $w t^{c}$ & $\triangle A \mid C_{C}$ & $w t$ & $\triangle A C_{C}$ & Wt \\
\hline \multicolumn{7}{|l|}{ 1. Distance added } \\
\hline Base & 0.00 & 0.86 & 0.00 & 0.91 & 0.00 & 0.47 \\
\hline$B+$ Tree & 3.83 & 0.13 & 4.69 & 0.09 & 0.51 & 0.37 \\
\hline$B+$ Tree $\times R$ & 10.42 & 0.00 & 13.77 & 0.00 & 2.26 & 0.15 \\
\hline$B+$ Tree $\times Y$ & 11.86 & 0.00 & 17.15 & 0.00 & 9.11 & 0.00 \\
\hline $\begin{array}{l}B+\text { Tree } \times R+\text { Tree } \times Y \\
\text { 2. Patch size added }\end{array}$ & \multicolumn{5}{|c|}{ 2. Patch size added } & 0.00 \\
\hline B1 & 0.00 & 0.75 & 0.00 & 0.81 & 0.00 & 0.81 \\
\hline $\mathrm{B} 1+\mathrm{Sz}$ & 2.26 & 0.24 & 3.19 & 0.17 & 3.43 & 0.15 \\
\hline $\mathrm{B} 1+\mathrm{Sz} \times \mathrm{R}$ & 8.68 & 0.01 & 7.49 & 0.02 & 7.77 & 0.02 \\
\hline $\mathrm{B} 1+\mathrm{Sz} \times \mathrm{Y}$ & 11.10 & 0.00 & 12.49 & 0.00 & 17.37 & 0.00 \\
\hline $\begin{array}{l}\mathrm{B} 1+\mathrm{Sz} \times \mathrm{R}+\mathrm{Sz} \times \mathrm{Y} \\
\text { 3. Landscape added }\end{array}$ & \multicolumn{5}{|c|}{ 3. Landscape added } & 0.00 \\
\hline $\mathrm{B} 2$ & 0.00 & 0.57 & 0.00 & 0.83 & 0.00 & 0.74 \\
\hline$B 2+L$ & 0.70 & 0.41 & 3.22 & 0.17 & 2.11 & 0.26 \\
\hline$B 2+L \times R$ & 7.41 & 0.01 & 11.10 & 0.00 & 10.35 & 0.00 \\
\hline$B 2+L \times Y$ & 9.70 & 0.00 & 15.37 & 0.00 & $x^{d}$ & \\
\hline$B 2+L \times R+L \times Y$ & 13.58 & 0.00 & 18.43 & 0.00 & & \\
\hline \multicolumn{7}{|c|}{ 4. Patch size $\times$ Landscape interaction added: final model } \\
\hline B3 & 0.00 & 0.88 & 0.00 & 0.73 & 0.00 & 0.73 \\
\hline $\mathrm{B} 3+\mathrm{Sz} \times \mathrm{L}$ & 3.93 & 0.12 & 2.04 & 0.27 & 1.98 & 0.27 \\
\hline
\end{tabular}

a The number of nests differs from the number of observations, because nesting data are split into 2 intervals (Shaffer 2004).

${ }^{b} \triangle \mathrm{AIC}_{\mathrm{C}}$ is the difference between the best fitting model and model $i$, adjusted for small sample sizes.

c Akaike weights indicate the importance of 1 model relative to the other models.

Attempts to fit models with year interactions did not converge. 
standard deviation $[\mathrm{SD}]=341.7$; range $=2.4-1,245.6$ ha; Appendix 1) compared with other studies documenting patch size effects on grassland birds (e.g., Winter and Faaborg 1999, Balent and Norment 2003; but see Ribic and Sample 2001). One could argue that our prairie patches might have been larger than the minimum size requirements of our study species. However, a second analysis using only prairie patches $<65 \mathrm{ha}(\bar{x}=21.0 \mathrm{ha}$, SD $=16.5$; range $=2.4-61.3$ ha, $n=24$ study plots) gave very similar results (M. Winter et al., State University of New York, unpublished data). The minor effect of patch size on bird density was therefore not due to the relatively large sizes of our study plots. Instead, the relatively low mean percentage of shrubs and trees in the landscape surrounding prairie patches $(\bar{x}=12.4 \%$, SD $=10.9 \%$ range $=1-46 \%$ ) probably caused those patches not to be deemed small by our focal bird species (see also Davis 2004).

\section{Response of Bird Density to Landscape Features}

Whereas the magnitude of the species' response to landscape varied among regions and years, the direction of the response largely stayed the same: with increasing percentage of shrubs and trees in the landscape, clay-colored sparrow density increased, whereas densities of Savannah sparrows and bobolinks decreased. This pattern is consistent with previous findings that clay-colored sparrows prefer shrubby habitats (Knapton 1994), whereas Savannah sparrows and bobolinks do not (Wheelwright and Rising 1993, Martin and Gavin 1995). Several previous studies have indicated that landscape influenced grassland bird abundance or density (e.g., Best et al. 2001, Coppedge et al. 2001, Ribic and Sample 2001, Fletcher and Koford 2002), whereas other studies did not find such an effect (Bajema and Lima 2001, Horn et al. 2002), or found that patch size had a greater effect than did landscape features (O'Connor et al. 1999).

The landscape effect in our study included only the effect of the percentage of shrubs and trees because of a lack of more detailed information on landscape cover. Behavioral observations indicated that bobolinks and Savannah sparrows often feed in croplands (M. Winter, State University of New York, personal observation). A limited amount of cropland in the surrounding landscape of a prairie patch might thus have a positive effect on this species. The use of surrounding areas for foraging could then partly explain the absence of consistent area effects in our study area (Estades 2001).

\section{A Matter of Design}

Landscape composition influenced the densities of all focal species more clearly than did patch size and had a greater effect on density than did vegetation features (Table 2). In contrast to these results, Bakker et al. (2002) reported from a study in eastern South Dakota that densities of clay-colored sparrows, Savannah sparrows, and bobolinks were not related to landscape variables but were influenced mainly by vegetation features. Such differences in the response of the same species to similar variables in the same general habitat are striking. We doubt that regional differences in habitat and landscape structure, and in bird populations, are the only causes for this discrepancy. The disparity may also be due to the different criteria for selecting study plots. We selected study plots to be as similar in vegetation structure as possible to minimize differences among plots based on vegetation structure and to maximize variation in patch size and landscape composition. It is therefore not surprising that in our study vegetation structure explained relatively little of the variation in grassland bird density. Bakker et al. (2002), on the other hand, randomly selected their study sites. Vegetation structure therefore probably differed more dramatically among their sites than in our study.

\section{Do Patch Size and Landscape Effects Interact?}

In our study, landscape effects did not differ between small and large prairie patches. To our knowledge, such interactive effects have also not been shown in any other study on grassland-nesting birds.

\section{Response of Nesting Success}

Based on model-averaged parameter estimates, nesting success was not consistently affected by patch size or landscape composition. This result was completely unexpected. Based on previous studies of grassland-breeding passerines (Johnson and Temple 1990, Davis and Sealy 2000, Winter and Faaborg 1999, Balent and Norment 2003, Herkert et al. 2003, Perkins et al. 2003), we were confident we would find that nesting success decreases with smaller patch size and with higher percentage of shrubs and trees in the landscape because such nests should be exposed to a larger number and variety of potential nest predators (e.g., Gates and Gysel 1978, Winter et al. 2000, Kuehl and Clark 2002). Particularly, we expected nesting success to be lowest in small prairies that were situated in a wooded landscape.

Nest predation was the main cause of nest loss in our study (Winter et al. 2004; see also Martin 1995), suggesting that variation in nest success was caused mainly by differences in the abundance or activities of nest predators. The lack of a consistent patch size and landscape effect on nesting success is consistent with the findings of studies on nest predators in grasslands (Bergin et al. 2000, Chalfoun et al. 2002b). These studies concluded that the distribution of nest predators in grasslands can be complex and difficult to use for management guidelines.

To our knowledge, only 3 studies have investigated the effect of multiple spatial scales on grassland bird nesting success (Howard et al. 2001, Davis 2003, Winter et al. 2005b); none of these studies found a consistent effect of a specific habitat scale on nesting success. Howard et al. (2001) did not find any effect of distance from edge, patch size, or landscape on nesting success in Colorado shortgrass prairie; but sample size was small ( $n=50$ nests), and nests were pooled among 5 different species. In the mixed-grass prairie of southern Saskatchewan, Davis (2003) investigated the influence of plot vegetation, distance to edge, and patch size on nesting success of 6 grassland passerines. Similar to our study, patch size also had a minor effect on grassland passerines, potentially due to the lack of woody edges (Davis 2003). Winter et al. (2005b) found that nesting success of Le Conte's sparrow in the northern tallgrass prairie was highly variable among years and regions. None of the investigated variables (vegetation, distance to edge, patch size, and landscape structure) had a clear effect on the species' nesting success; however, sample size was small $(n=50)$.

\section{Comparison of Factors Influencing Density and Nesting Success}

Bird density and nesting success were influenced by completely different factors. It is therefore not possible to use factors that 
influence bird density to predict nesting success. Few other studies have investigated both density and nesting success and have compared the factors influencing these variables. Several studies on dickcissels (Spiza americana) have documented that factors influencing the species' density differed from those influencing nesting success (e.g., Hughes et al. 1999, Winter and Faaborg 1999). In the Canadian mixed-grass prairie, Davis (2003) detected an inverse relationship between density and nesting success of Sprague's pipits (Anthus spragueii), whereas density and nesting success of 5 other passerines were not correlated. In desert shrublands, abundance of black-throated sparrows (Amphispiza bilineata) did not accurately reflect rates of the species' nesting success (Pidgeon et al. 2003). For forest-nesting birds, Fauth et al. (2000) demonstrated that density is not a useful index of nesting success. The authors concluded, "The potential for developing conservation strategies ... will be limited without labor-intensive, direct measurements of demographic parameters." In theory, we agree with this statement. However, the fact that we could not demonstrate any factor that clearly affected nesting success (despite the large number of nests) suggests to us that in our study system, the value of information obtained from nesting data may not justify the tremendous effort necessary to collect those data. This is not to say that nesting data are not of importance in other areas, and for other research questions.

In summary, our study clearly indicates the need for replication at a large scale (metareplication, Johnson 2002) because the direction and magnitude of the response of bird density and nesting success to patch size and landscape composition varied among years, regions, and species. In a recent review of studies that investigate the effect of habitat fragmentation on nest success, Stephens et al. (2004) also emphasized the need for large-scale studies. The high variability in our study system suggests that extrapolation from small-scale studies should-at best-be done with caution when developing management guidelines. However, we do not recommend that small-scale studies be abandoned. Most advanced degree students will lack the financial support or time to conduct large-scale, long-term studies. We make 4 suggestions to improve the usefulness of short-term studies: 1) replication of existing studies to test if similar results are obtained in different regions and years (Johnson 2002); 2) inclusion of several small-scale studies within a large-scale study; 3) investigation of topics that are likely to have relatively low annual and regional variation; and 4) use of existing data to analyze large-scale questions, such as data from the Breeding Bird Survey (http:// www.pwrc.usgs.gov/bbs/).

\section{Management Implications}

Our study indicates that conservation actions in treeless landscapes need to focus on local habitat structure and landscape composition. Patch size, and thus the size of a core area in a BCA, might not be as relevant to grassland passerines as previously proposed, when prairie patches are located in treeless landscapes. Large core areas are likely to be more important in regions where grassland patches are smaller in size and where the surrounding landscape is covered by a higher percentage of shrubs and trees, such as the northeastern United States (Balent and Norment 2003). We expect that the specific requirements for the size of a core area will vary among regions, depending on 1) the quality of the core prairie itself, 2) the amount of forest in the surrounding landscape, and 3) the local predator community (Chalfoun et al. 2002a,b).

Certainly, larger prairie patches will always be better than small patches because 1) they preserve a larger number of individuals of a given species (Horn et al. 2001, Johnson 2001), 2) large prairie patches might support a less variable and thus less extinctionsusceptible local bird community (Boulinier et al. 1998), and 3) some nonpasserine bird species-such as the greater prairie chicken (Tympanuchus tympanuchus) - require large continuous prairie patches (e.g., Niemuth 2000, M. Winter et al., State University of New York, unpublished data). However, we are concerned that the focus on large prairie patches might neglect small patches that are also worth preserving because 1) several small habitat patches surrounded by treeless landscape might offer similar conservation value for some grassland passerines as a single large prairie (see also Davis 2004); 2) even if smaller patches were of lower quality than large patches, such patches might be important as prime breeding habitat for subordinate first-year breeders (as shown for the collared flycatchers, Ficedula albicollies, by Doligez et al. 2004); 3) some small prairie patches might harbor rare species other than birds-such as the western prairie fringed orchid (Platanthera praeclara; Hof et al. 1999); and 4) small patches are less expensive to acquire and easier to manage, and are therefore more likely to be protected by local conservation agencies and landowners. This recommendation excludes small patches that are surrounded by forest and shrubland because such patches might be population sinks for grassland birds due to high rates of nest predation (e.g., Winter and Faaborg 1999, Perkins et al. 2003).

Our observation of high interannual and interregional variation in bird density indicates that managers should not rely too heavily on specific numbers and guidelines. When management recommendations are based on short-term, small-scale studies, they may not be appropriate for a particular grassland patch. We strongly believe that once an area is chosen for the conservation of grassland birds, management will be most effective if decision rules are refined to the specific needs of the grassland patch. Such refinement requires the integration of management guidelines that are derived from previous studies with knowledge that is obtained from personal experience. Such refined decision rules can then be further adjusted to local needs based on the results of previous management action, as it is customary in adaptive resource management (e.g., Nichols et al. 1995, Aldridge et al. 2004).

\section{Acknowledgments}

We thank the more than 40 field assistants who showed great enthusiasm. We thank R. Julian of the U.S. Fish and Wildlife Service; B. M. and S. Winter and the late G. Yalch of The Nature Conservancy; and B. Stotts of the U.S. Forest Service for generous assistance with housing and other logistics. Access to study areas was granted by The Nature Conservancy, U.S. Fish and Wildlife Service, U.S. Forest Service, and the Minnesota Department of Natural Resources (Division of Fish and Wildlife and Division of Parks and Recreation). J. E. Austin, the late D. P. Fellows, P. J. Pietz, and M. A. Sovada of the Northern Prairie Wildlife Research Center loaned equipment and supplies. B. R. Euliss 
assisted the project in numerous ways and developed the patch size and landscape data. T. L. Shaffer provided the guidelines for analysis of nesting data, and W. M. Hochachka helped with analytical and programming questions. The Cornell Laboratory of Ornithology and the Vogelwarte Radolfzell of the Max Planck Institute for Ornithology provided working facilities for the first

\section{Literature Cited}

$\rightarrow$ Aldridge, C. L., M. S. Boyce, and R. K. Baydack. 2004. Adaptive management of prairie grouse: how do we get there? Wildlife Society Bulletin 32:92-103.

$\rightarrow$ Anderson, D. R., K. P. Burnham, and W. L. Thompson. 2000. Null hypothesis testing: problems, prevalence, and an alternative. Journal of Wildlife Management 64:912-923.

$\rightarrow$ Bajema, R. A., and S. L. Lima. 2001. Landscape-level analyses of Henslow's sparrow (Ammodramus henslowii) abundance in reclaimed coal mint $\rightarrow$ grasslands. American Midland Naturalist 145:288-298.

$\rightarrow$ Bakker, K. K., D. E. Naugle, and K. F. Higgins. 2002. Incorporating landscape attributes into models for migratory grassland bird conservation. Conserva $\rightarrow$ tion Biology 16:1638-1646.

$\rightarrow$ Balent, K. L., and C. J. Norment. 2003. Demographic characteristics of a grasshopper sparrow population in a highly fragmented landscape $0 \rightarrow$ western New York State. Journal of Field Ornithology 74:341-348.

Bergin, T. M., L. B. Best, K. E. Freemark, and K. J. Koehler. 2000. Effects of landscape structure on nest predation in roadsides of a midwestern agroecosystem: a multiscale analysis. Landscape Ecology 15:131-143.

$\rightarrow$ Best, L. B., T. M. Bergin, and K. E. Freemark. 2001. Influence of landscape composition on bird use of rowcrop fields. Journal of Wildlife Management 65:442-449.

$\rightarrow$ Best, L. B., H. Campa, K. E. Kemp, R. J. Robel, M. R. Ryan, J. A Savidge, H. P. Weeks, and S. R. Winterstein. 1997. Bird abundance and nesting in CRP fields and cropland in the midwest: a regional approach. Wildlife Society Bulletin 25:864-877.

Bollinger, E. K., and T. A. Gavin. 1992. Eastern Bobolink populations: ecology and conservation in an agricultural landscape. Pages 497-506 in J. M. Hagan, III, and D. W. Johnston, editors. Ecology and conservation $0 \rightarrow$ neotropical migrant landbirds. Smithsonian Institution, Washington, D.C., USA.

$\rightarrow$ Bollinger, E. K., and T. A. Gavin. 2004. Responses of nesting bobolink: $\rightarrow$ (Dolichonyx oryzivorus) to habitat edges. Auk 121:767-776.

$\rightarrow$ Boulinier, T., J. D. Nichols, J. E. Hines, J. R. Sauer, C. H. Flather, and K. H $\rightarrow$ Pollock. 1998. Higher temporal variability of forest breeding bird communities in fragmented landscapes. Proceedings of the National Academy of Sciences USA 95:7497-7501.

Burnham, K. P., and D. R. Anderson. 2002. Model selection and inference: a practical information-theoretic approach. Second edition. Springer, New York, New York, USA.

$\rightarrow$ Chalfoun, A. D., M. J. Ratnaswamy, and F. R. Thompson, III. 2002a. Songbird nest predators in forest-pasture edge and forest interior in a fragmented landscape. Ecological Applications 12:858-867.

$\rightarrow$ Chalfoun, A. D., F. R. Thompson, III, and M. J. Ratnaswamy. 2002b. Nest predators and fragmentation: a review and meta-analysis. Conservation Biology 16:306-318.

Chapman, K. A., A. Fischer, and M. K. Ziegenhagen. 1998. Valley of grass $\rightarrow$ tallgrass prairie and parkland of the Red River region. North Star, St. Cloud, Minnesota, USA.

$\rightarrow$ Coppedge, B. R., D. M. Engle, R. E. Masters, and M. S. Gregory. 2001. Avian response to landscape change in fragmented southern Great Plains grasslands. Ecological Applications 11:47-59.

Davis, S. K. 2003. Habitat selection and demography of mixed-grass prairie songbirds in a fragmented landscape. Dissertation, University of Regina, Regina, Saskatchewan, Canada.

$\rightarrow$ Davis, S. K. 2004. Area sensitivity in grassland passerines: effects of patch size, patch shape, and vegetation structure on bird abundance anc $\rightarrow$ occurrence in southern Saskatchewan. Auk 121:1130-1145.

Davis, S. K., and S. G. Sealy. 2000. Cowbird parasitism and nest predation in fragmented grasslands of southwestern Manitoba. Pages 220-228 in J. N. M. Smith, T. L. Cook, S. I. Rothstein, S. K. Robinson, and S. G. Sealy, editors. Ecology and management of cowbirds and their hosts. University of Texas Press, Austin, USA. author. The manuscript was greatly improved by comments from W. Fiedler, J. Fitzgerald, W. M. Hochachka, F. Pullido, and 2 anonymous reviewers. The study was funded by the U.S. Geological Survey; the U.S. Fish and Wildlife Service, Regions 3 and 6; and the Northwest Research and Outrearch Center at the University of Minnesota, Crookston.

Dieni, J. S., and S. L. Jones. 2003. Grassland songbird nest site selection patterns in northcentral Montana. Wilson Bulletin 115:388-396.

Doligez, B., T. Part, E. Danchin, J. Clobert, and L. Gustafsson. 2004. Availability and use of public information and conspecific density for settlement decisions in the collared flycatcher. Journal of Animal Ecology 73:75-87.

Donovan, T. M., P. W. Jones, E. M. Annand, and F. R. Thompson, III. 1997. Variation in local scale edge effects: mechanisms and landscape context. Ecology 78:2064-2075.

Donovan, T. M., F. R. Thompson, III, J. Faaborg, and J. R. Probst. 1995. Reproductive success of migratory birds in habitat sources and sinks. Conservation Biology 9:1380-1395.

Driscoll, M. J. L., and T. M. Donovan. 2004. Landscape context moderates edge effects: nesting success of wood thrushes in central New York. Conservation Biology 18:1330-1338.

Estades, C. F. 2001. The effect of breeding-habitat patch size on bird population density. Landscape Ecology 16:161-173.

Fauth, P. T., E. J. Gustafson, and K. N. Rabenold. 2000. Using landscape metrics to model source habitat for neotropical migrants in the midwestern US. Landscape Ecology 15:621-631.

Fitzgerald, J. A., D. N. Pashley, S. J. Lewis, and B. Pardo. 1998. Partners in flight bird conservation plan for the northern tallgrass prairie (physiographic area 40). American Bird Conservatory, The Plains, Virginia, USA.

$\rightarrow$ Fletcher, R. J., and R. R. Koford. 2002. Habitat and landscape associations of breeding birds in native and restored grasslands. Journal of Wildlife Management 66:1011.

Fletcher, R. J., and R. R. Koford. 2003. Spatial responses of bobolinks (Dolichonyx oryzivorus) near different types of edges in northern lowa. Auk 120:799-810.

Gates, J. E., and L. W. Gysel. 1978. Avian nest dispersion and fledging success in field-forest ecotones. Ecology 59:871-883.

George, T. L., A. C. Fowler, R. L. Knight, and L. C. McEven. 1992. Impacts of a severe drought on grassland birds in western North Dakota. Ecological Applications 2:275-284.

$\rightarrow$ Helzer, C. J., and D. E. Jelinski. 1999. The relative importance of patch area and perimeter-area ratio to grassland breeding birds. Ecological Applications 9:1448-1458.

Henderson, R. A., and D. W. Sample. 1995. Grassland communities. Pages 116-129 in J. Addis, editor. Wisconsin's biodiversity as a management issue: a report to Department of Natural Resources' managers. Wisconsin Department of Natural Resources, Madison, USA.

Herkert, J. R. 1994a. Breeding bird communities of midwestern prairie fragments: the effects of prescribed burning and habitat-area. Natural Areas Journal 14:128-135.

Herkert, J. R. 1994b. The effect of habitat fragmentation on midwestern grassland bird communities. Ecological Applications 9:1448-58.

$\rightarrow$ Herkert, J. R., D. L. Reinking, D. A. Wiedenfeld, M. Winter, J. L. Zimmerman, W. E. Jensen, E. J. Finck, R. R. Koford, D. H. Wolfe, S. K. Sherrod, M. A. Jenkins, J. Faaborg, and S. K. Robinson. 2003. Effects of prairie fragmentation on the nest success of breeding birds in the mid-continental United States. Conservation Biology 17:587-594.

Hof, J., C. H. Sieg, and M. Beyers. 1999. Spatial and temporal optimization in habitat placement for a threatened plant: the case of the western prairie fringed orchid. Ecological Modelling 115:61-75.

$\rightarrow$ Horn, D. J., R. F. Fletcher, Jr., and R. R. Koford. 2001. Detecting area sensitivity: a comment on previous studies. American Midland Naturalist 144:28-35

Horn, D. J., R. R. Koford, and M. L. Braland. 2002. Effects of field size and landscape composition on grassland birds in south-central lowa. Journal of the lowa Academy of Science 109:1-7.

$\rightarrow$ Howard, M. N., S. K. Skagen, and P. L. Kennedy. 2001. Does habitat 
fragmentation influence nest predation in the shortgrass prairie? Condor 103:530-536.

$\rightarrow$ Hughes, J. P., R. J. Robel, K. E. Kemp, and J. L. Zimmerman. 1999. Effects of habitat on dickcissel abundance and nest success in Conservation Reserve Program fields in Kansas. Journal of Wildlife Management 63:523-529.

Igl, L. D., and D. H. Johnson. 1997. Changes in breeding bird populations in North Dakota: 1967 to 1992-93. Auk 114:74-92.

Igl, L. D., and D. H. Johnson. 1999. Le Conte's sparrows breeding ir Conservation Reserve Program fields: precipitation and patterns of population change. Studies in Avian Biology 19:178-186.

Johnson, D. H. 2001. Habitat fragmentation effects on birds in grasslands and wetlands: a critique of our knowledge. Great Plains Research 11:211-213.

$\rightarrow$ Johnson, D. H. 2002. The importance of replication in wildlife research. Journal of Wildlife Management 66:919-932.

$\rightarrow$ Johnson, D. H., and L. D. Igl. 2001. Area requirements of grassland birds: a regional perspective. Auk 118:24-34.

$\rightarrow$ Johnson, R. G., and S. A. Temple. 1990. Nest predation and brood parasitism of tallgrass prairie birds. Journal of Wildlife Management 54:106-111.

Knapton, R. W. 1994. Clay-colored sparrow (Spizella pallida). In A. Poole, and F. Gill, editors. Birds of North America, No. 120. The Academy of Naturar Sciences, Philadelphia, Pennsylvania, USA; The American Ornithologist's Union, Washington, D.C., USA.

Koford, R. R. 1999. Density and fledging success of grassland birds in Conservation Reserve Program fields in North Dakota and west-central Minnesota. Studies in Avian Biology 19:187-195.

$\rightarrow$ Kuehl, A. K., and W. R. Clark. 2002. Predator activity related to landscape features in northern lowa. Journal of Wildlife Management 66:1224-1234.

Littell, R. C., P. R. Henry, and C. B. Ammerman. 1996. Mixed model SAS procedures with emphasis on repeated measures. Journal of Animal Science 74:274.

Martin, S. G., and T. A. Gavin. 1995. Bobolink (Dolichonyx oryzivorus). In A. Poole, and F. Gill, editors. Birds of North America, No. 176. The Academy of Natural Sciences, Philadelphia, Pennsylvania, USA; The American Ornithologist's Union, Washington, D.C., USA.

$\rightarrow$ Martin, T. E. 1995. Avian life history evolution in relation to nest sites, nes ${ }^{+}$ predation, and food. Ecological Monographs 65:101-126.

$\rightarrow$ Nichols, J. D, F. A. Johnson, and B. K. Williams. 1995. Managing NorthAmerican waterfowl in the face of uncertainty. Annual Review of Ecology and Systematics 26:177-199.

$\rightarrow$ Niemuth, N. D. 2000. Land use and vegetation associated with greater prairiechicken leks in an agricultural landscape. Journal of Wildlife Management 64 278-286.

O'Connor, R. J., M. T. Jones, R. B. Boone, and T. B. Lauber. 1999. Linkin continental climate, land use, and land use patterns with grassland bird distribution across the conterminous United States. Studies in Avian Biology 19:45-59.

$\rightarrow$ Perkins, D. W., P. D. Vickery, and W. G. Shriver. 2003. Spatial dynamics of source-sink habitats: effects on rare grassland birds. Journal of Wildlife Management 67:588-599.

$\rightarrow$ Pidgeon, A. M., V. C. Radeloff, and N. E. Mathews. 2003. Landscape-scale patterns of black-throated sparrow (Amphispiza bilineata) abundance and nest success. Ecological Applications 13:530-542.

$\rightarrow$ Renfrew, R. B., and C. A. Ribic. 2002. Influence of topography on density of grassland passerines in pastures. American Midland Naturalist 147:315325.

$\rightarrow$ Ribic, C. A., and D. W. Sample. 2001. Associations of grassland birds with landscape factors in southern Wisconsin. American Midland Naturalist 146: 105-121.

$\rightarrow$ Robinson, S. K., F. R. Thompson, III, T. M. Donovan, D. R. Whitehead, and J.
Faaborg. 1995. Regional forest fragmentation and the nesting success of migratory birds. Science 267:1987-1990.

SAS Institute Inc. 1999. The SAS system for Windows, version 8.0. SAS Institute, Cary, North Carolina, USA.

Sauer, J. R., J. E. Hines, and J. Fallon. 2004. The North American breeding bird survey, results and analysis 1966-2003. Version 2004.1. USGS Patuxent Wildlife Research Center, Laurel, Maryland, USA.

Scheiman, D. M., E. K. Bollinger, and D. H. Johnson. 2003. Effects of leafy spurge infestation on grassland birds. Journal of Wildlife Management 67: 115-121.

Shaffer, T. L. 2004. A unified approach to analyzing nest success. Auk 12: $526-540$.

Stephens, S. E., D. N. Koons, J. J. Rotella, and D. W. Willey. 2004. Effects of habitat fragmentation on avian nesting success: a review of the evidence at multiple spatial scales. Biological Conservation 115:101-110.

$\rightarrow$ Van Horne, B. 1983. Density as a misleading indicator of habitat quality. Journal of Wildlife Management 47:893-901.

$\rightarrow$ Vickery, P. D., M. L. Hunter, and J. V. Wells. 1992. Is density an indicator of breeding success? Auk 109:706-710.

$\rightarrow$ Walk, J. W., and R. E. Warner. 1999. Effects of habitat area on the occurrence of grassland birds in Illinois. American Midland Naturalist. 141:339-344.

Wheelwright, N. T., and J. D. Rising. 1993. Savannah sparrow (Passerculus sandwichensis). In A. Poole, and F. Gill, editors. Birds of North America, No. 45. The Academy of Natural Sciences, Philadelphia, Pennsylvania, USA; The American Ornithologist's Union, Washington, D.C., USA.

Wiens, J. A. 1969. An approach to the study of ecological relationships among grassland birds. Ornithological Monographs 8. American Ornithologists' Union, Washington D.C., USA.

Wiens, J. A. 1981. Scale problems in avian censusing. Studies in Avian Biology 6:513-521.

Wiens, J. A. 2001. Predicting species occurrences: progress, problems, and prospects. Pages 739-749 in J. M. Scott, P. J. Heglund, J. B. Haufler, M. Morrison, M. G. Raphael, W. B. Wall, and F. Samson, editors. Predicting species occurrences: issues of accuracy and scale. Island, Washington D.C., USA.

$\rightarrow$ Wiens, J. A., J. T. Rotenberry, and B. Van Horne. 1987. Habitat occupancy patterns of North American shrubsteppe birds: the effect of spatial scale. Oikos 48:132-147.

Winter, M., and J. Faaborg. 1999. Varying patterns of area-sensitivity in grassland-nesting birds. Conservation Biology 13:1324-1434.

Winter, M., S. E. Hawks, J. A. Shaffer, and D. H. Johnson. 2003. Guidelines for finding nests of passerine birds in tallgrass prairie. Prairie Naturalist 35:197211.

Winter, M., D. H. Johnson, and J. Faaborg. 2000. Evidence for edge effects on multiple levels: artificial nests, natural nests, and distribution of nest predators in Missouri tallgrass prairie fragments. Condor 102:256-266.

$\rightarrow$ Winter, M., D. H. Johnson, and J. A. Shaffer.6 2005a. Variability in vegetation effects on density and nesting success of grassland birds. Journal of Wildlife Management 69:185-197.

$\rightarrow$ Winter, M., D. H. Johnson, J. A. Shaffer, and W. D. Svedarsky. 2004. Nesting biology of three grassland passerines in the northern tallgrass prairie. Wilson Bulletin 116:211-223.

$\rightarrow$ Winter, M., J. A. Shaffer, D. H. Johnson, T. M. Donovan, W. D. Svedarsky, P. W. Jones, and B. R. Euliss. 2005b. Habitat and nesting of Le Conte's sparrows in the northern tallgrass prairie. Journal of Field Ornithology 76:61-71.

Wolfinger, R., and M. O'Connell. 1993. Generalized linear mixed models: a pseudo-likelihood approach. Journal of Statistical Computation and Simulation 48:233-243.

Associate Editor: Rodewald. 
Appendix 1. Study plots in northwestern Minnesota (Crookston and Glyndon) and southeastern North Dakota (Sheyenne), USA, 1998-2001. For each study plot the following variables are shown: size of the study plot, size of the contiguous grassland patch, and the percentage of shrubs and trees within a 200-m buffer (Land). Study plots are ordered by patch size. Prairie names were invented if names of prairie patches were not available (*). Nonnative grasslands are indicated by a superscript $\mathrm{N}$, and prairies on which we annually searched for nests are indicated by a superscript $\mathrm{S}$. Sheyenne prairies were native, but intermixed with non-native plants.

\begin{tabular}{|c|c|c|c|c|}
\hline Region & Prairie & Study plot (ha) & Patch (ha) & Land \\
\hline \multirow[t]{15}{*}{ Crookston } & MentorNW & 2.6 & 6.2 & 34.5 \\
\hline & Shypoke ${ }^{\mathrm{s}}$ & 3.4 & 8.6 & 0.0 \\
\hline & Tildens & 8.3 & 13.9 & 33.8 \\
\hline & MentorSE & 8.8 & 15.2 & 28.7 \\
\hline & MentorSN ${ }^{S}$ & 7.6 & 19.4 & 4.4 \\
\hline & Dugdale $^{\text {N.S }}$ & 6.8 & 19.7 & 2.5 \\
\hline & ChicogSH $^{\text {N,S }}$ & 3.4 & 26.4 & 30.8 \\
\hline & ChicogLH ${ }^{N}$ & 11.8 & 42.5 & 13.9 \\
\hline & Foxboros & 5.7 & 61.0 & 5.5 \\
\hline & Burnham ${ }^{s}$ & 12.5 & 104.9 & 4.0 \\
\hline & PankratzN ${ }^{s}$ & 16.0 & 109.7 & 0.0 \\
\hline & PankratzL $\mathrm{H}^{\mathrm{s}}$ & 20.6 & 234.1 & 14.9 \\
\hline & Pankratzs ${ }^{s}$ & 15.1 & 234.1 & 0.1 \\
\hline & Tympanuchus ${ }^{s}$ & 16.6 & 436.8 & 1.7 \\
\hline & Pembina Trail ${ }^{N}$ & 15.1 & 498.1 & 1.9 \\
\hline \multirow[t]{18}{*}{ Glyndon } & BuffaloSH & 2.9 & 4.6 & 49.2 \\
\hline & Private ${ }^{* S}$ & 4.0 & 8.0 & 21.0 \\
\hline & Ulens & 5.5 & 10.6 & 17.6 \\
\hline & Spring Creek $s$ & 8.4 & 13.2 & 0.0 \\
\hline & Sagebraaten & 2.8 & 13.3 & 1.9 \\
\hline & Refuge*S & 9.0 & 15.7 & 0.8 \\
\hline & Zimmerman & 7.7 & 28.0 & 6.1 \\
\hline & Flickertail $^{\mathrm{N}}$ & 12.3 & 29.4 & 17.2 \\
\hline & Eide & 2.3 & 30.9 & 5.0 \\
\hline & Fuglie $^{N}$ & 17.6 & 42.6 & 13.9 \\
\hline & Rice-Elliott & 16.1 & 143.0 & 0.0 \\
\hline & Hoykens s & 5.8 & 154.4 & 4.0 \\
\hline & Margherita & 12.0 & 155.6 & 1.5 \\
\hline & Bicentennial $^{\mathrm{S}}$ & 16.1 & 427.4 & 3.3 \\
\hline & Blazing Star & 16.2 & 427.4 & 0.0 \\
\hline & BluestemLH S & 14.7 & 1245.6 & 29.4 \\
\hline & BluestemLN's & 15.5 & 1245.6 & 3.7 \\
\hline & BuffaloLH ${ }^{s}$ & 16.4 & 1245.6 & 19.3 \\
\hline \multirow[t]{11}{*}{ Sheyenne } & Surprise ${ }^{*}$ & 1.3 & 2.4 & 39.7 \\
\hline & Shrike ${ }^{\star S}$ & 1.7 & 4.8 & 44.0 \\
\hline & Pileated ${ }^{* S}$ & 7.4 & 11.3 & 55.9 \\
\hline & Camps & 9.3 & 14.9 & 38.2 \\
\hline & Eagle $^{\star S}$ & 15.2 & 61.3 & 19.5 \\
\hline & Hammock* & 12.9 & 220.1 & 17.6 \\
\hline & Highway*S & 18.1 & 283.4 & 4.2 \\
\hline & Savannah $^{+S}$ & 13.8 & 326.9 & 6.4 \\
\hline & SouthEasi๋ & 14.1 & 418.8 & 0.3 \\
\hline & Plum*S & 17.1 & 705.5 & 0.1 \\
\hline & North ${ }^{\star S}$ & 17.3 & 826.5 & 0.0 \\
\hline
\end{tabular}

Appendix 2. Model-averaged results of the final model (from Table 2) that describes the influence of vegetation variables (vegetation height [Height], percent woody cover in a Daubenmire frame [WoodCover], and litter depth), patch size (Size), and percentage shrubs and trees within a 200-m buffer zone (Land) on density of 3 grassland-nesting species of the northern tallgrass prairie, 1998-2001.

\begin{tabular}{|c|c|c|c|c|c|c|}
\hline Species & Effect & Year & Region & Estimate & $\mathrm{LCI}$ & $\mathrm{UCl}$ \\
\hline Clay-colored & Intercept & & & 28.457 & -19.820 & 76.734 \\
\hline \multirow[t]{20}{*}{ Sparrow } & (Height) $^{2}$ & & & $\ldots .008$ & -0.012 & -0.003 \\
\hline & WoodCover & & & 3.074 & 1.658 & 4.491 \\
\hline & Year & 1998 & & -0.429 & -20.158 & 19.301 \\
\hline & & 1999 & & 3.899 & -13.101 & 20.898 \\
\hline & & 2000 & & -4.914 & -19.264 & 9.435 \\
\hline & Region & & Crookston & 1.987 & -49.581 & 53.554 \\
\hline & & & Glyndon & 30.540 & -19.161 & 80.241 \\
\hline & Size $\times$ region & & Crookston & 0.080 & -0.035 & 0.194 \\
\hline & & & Glyndon & 0.043 & -0.048 & 0.134 \\
\hline & Size $\times$ year & 1998 & & -0.003 & -0.093 & 0.087 \\
\hline & & 1999 & & -0.041 & -0.129 & 0.046 \\
\hline & & 2000 & & -0.028 & -0.116 & 0.059 \\
\hline & & 2001 & & -0.057 & -0.145 & 0.030 \\
\hline & Land $x$ region & & Crookston & 1.802 & 0.226 & 3.379 \\
\hline & & & Glyndon & 1.094 & -0.420 & 2.608 \\
\hline & Land $x$ year & 1998 & & -0.723 & -2.202 & 0.756 \\
\hline & & 1999 & & 1.053 & -0.241 & 2.347 \\
\hline & & 2000 & & 0.105 & -1.259 & 1.468 \\
\hline & & 2001 & & 0.252 & -1.084 & 1.588 \\
\hline & Size $\times$ land & & & 0.000 & -0.001 & 0.002 \\
\hline \multirow{11}{*}{$\begin{array}{l}\text { Savannah } \\
\text { Sparrow }\end{array}$} & Intercept & & & 50.958 & -30.201 & 132.118 \\
\hline & (Litter depth) $^{2}$ & & & -0.267 & -0.478 & -0.055 \\
\hline & Region & & Crookston & 105.774 & 17.127 & 194.422 \\
\hline & & & Glyndon & 66.449 & -19.112 & 152.010 \\
\hline & Size $\times$ region & & Crookston & 0.049 & -0.086 & 0.183 \\
\hline & & & Glyndon & -0.023 & -0.070 & 0.025 \\
\hline & & & Sheyenne & 0.117 & -0.031 & 0.264 \\
\hline & Land $x$ region & & Crookston & -2.465 & -4.064 & -0.866 \\
\hline & & & Glyndon & -2.310 & -3.711 & -0.909 \\
\hline & & & Sheyenne & -1.070 & -3.156 & 1.017 \\
\hline & Size $x$ land & & & 0.000 & -0.002 & 0.003 \\
\hline \multirow[t]{17}{*}{ Bobolink } & Intercept & & & 36.714 & 10.888 & 62.540 \\
\hline & Height $\times$ region & & Crookston & 0.190 & -0.368 & 0.749 \\
\hline & & & Glyndon & 0.761 & 0.225 & 1.298 \\
\hline & & & Sheyenne & 1.780 & 0.988 & 2.573 \\
\hline & Size $\times$ region & & Crookston & 0.033 & -0.038 & 0.103 \\
\hline & & & Giyndion & -0.020 & -0.059 & 0.019 \\
\hline & & & Sheyenne & -0.067 & -0.127 & -0.007 \\
\hline & Size $x$ year & 1998 & & 0.044 & 0.007 & 0.081 \\
\hline & & 1999 & & 0.015 & -0.018 & 0.047 \\
\hline & & 2000 & & 0.001 & -0.028 & 0.030 \\
\hline & Land $\times$ region & & Crookston & -0.757 & -1.615 & 0.102 \\
\hline & & & Glyndon & -1.016 & $\ldots 1.843$ & -0.189 \\
\hline & & & Sheyenne & -1.057 & -2.007 & -0.108 \\
\hline & Land $x$ year & 1998 & & -0.865 & -1.613 & -0.117 \\
\hline & & 1999 & & -0.127 & -0.693 & 0.440 \\
\hline & & 2000 & & -0.320 & -0.792 & 0.152 \\
\hline & Size $\times$ land & & & 0.000 & -0.001 & 0.001 \\
\hline
\end{tabular}

Abbreviations: $\mathrm{LCl}$, lower confidence limit; $\mathrm{UCl}$, upper confidence limit. 
Appendix 3. Model-averaged results with lower confidence limits ( $\mathrm{LCl}$ ) and upper confidence limits (UCl) of the final model (from Table 4) that describes the influence of vegetation variables, bird density, climate, distance to trees (Distance), patch size (Size), and percentage shrubs and trees within a 200-m buffer zone (Land) on nesting success of 3 grassland-nesting species of the northern tallgrass prairie, 1998-2001.

\begin{tabular}{lcrrr}
\hline Species & Effect & Estimate & LCI & UCI \\
\hline Clay-colored sparrow & Intercept & 2.067 & 1.483 & 2.650 \\
& Density & 0.005 & 0.000 & 0.011 \\
& Nest cover $\times$ date & 0.000 & 0.000 & 0.000 \\
& Distance & 0.000 & -0.001 & 0.001 \\
& Size & 0.000 & -0.001 & 0.000 \\
& Land & -0.009 & -0.022 & 0.003 \\
& Size $\times$ land & 0.000 & 0.000 & 0.000 \\
Savannah sparrow & & & & \\
& Intercept & 2.837 & 2.089 & 3.585 \\
& Density & 0.001 & -0.003 & 0.005 \\
& Size & 0.000 & -0.001 & 0.000 \\
& Land & -0.004 & -0.029 & 0.021 \\
& Size $\times$ land & 0.000 & 0.000 & 0.000 \\
& & & & \\
Bobolink & Intercept & 2.844 & 2.153 & 3.536 \\
& Density $\times$ climate & 0.000 & -0.002 & 0.002 \\
& Distance $\times$ region: & & & \\
& Crookston & -0.001 & -0.002 & 0.001 \\
& Glyndon & 0.000 & -0.002 & 0.002 \\
& Sheyenne & -0.001 & -0.004 & 0.002 \\
& Size & 0.000 & -0.001 & 0.001 \\
& Land & 0.000 & -0.027 & 0.027 \\
& Size $\times$ land & 0.000 & 0.000 & 0.000 \\
\hline
\end{tabular}

